\title{
Carbapenem-resistant Acinetobacter baumannii in Adult Intensive Care Units: Risk Factors for Colonization and Infection
}

\author{
Yetişkin Yoğun Bakım Ünitelerinde Karbapenem-Dirençli Acinetobacter baumannii: \\ Kolonizasyon ve Enfeksiyon için Risk Faktörleri
}

\author{
(D) Neriman AKSU KOCA1, (D) Irmak BARAN1, (D) Meltem Arzu YETKIN², (D) Dilek KANYILMAZ3, (D) ipek MUMCUOĞLU1, \\ (D) Hatice YAĞMURDUR4 ${ }^{4}$, (D) Aliye BAŞTUĞ2, (D) Sema ALAÇAM1, (D) Nevzat Mehmet MUTLU4, (D) Hürrem BODUR2 \\ ${ }_{1}^{1}$ Ankara Numune Training and Research Hospital, Medical Microbiology Laboratory, Ankara, Turkey \\ ${ }^{2}$ Ankara Numune Training and Research Hospital, Clinic of Infectious Diseases and Clinical Microbiology, Ankara, Turkey \\ ${ }^{3}$ Ankara Numune Training and Research Hospital, Infection Control Committee, Ankara, Turkey \\ ${ }^{4}$ Ankara Numune Training and Research Hospital, Clinic of Anesthesiology, Reanimation and Intensive Care, Ankara, Turkey
}

\section{Abstract}

Introduction: Carbapenem-resistant Acinetobacter baumannii (CRAB) isolates are serious threats in intensive care units (ICUs). In this study, we aimed to investigate the risk factors associated with CRAB colonization and infection among adult ICU patients.

Materials and Methods: Patients hospitalized in the surgical/medical ICU for more than 48 hours were screened for CRAB acquisition. Environmental cultures were also performed. Identification and antibiotic susceptibility were determined with Vitek 2 (bioMérieux, France). bla ${ }_{O X A-23}, b_{1} a_{O X A-40}$ $b / a_{O X A-51}$ and $b / a_{O X A-58}$ genes were investigated by a multiplex polymerase chain reaction (Hyplex ${ }^{\circledR}$ Carb0xa ID, Germany). DiversiLab (bioMérieux, France) was used for clonal relationship analysis. Chi-square and t-test were used for comparison of data. Logistic regression backward LR model was performed to assess factors independently associated with ICU CRAB acquisition.

Results: Three hundred and ten patients were screened and 103 (33.2\%) were found to be colonized with CRAB. bla $a_{O X A-23}$ and bla $a_{O X-51}$ genes were found to be positive in all. DiversiLab showed that majority of the isolates came from a single clone. Clinical infection versus asymptomatic carriage ratio was approximately 1:2. Status of unconsciousness [ $p=0.049,0 R: 2.37$ (95\% Cl: 1.35-4.14)], staying $\geq 15$ days in ICU [p=0.000, $0 R$ : 6.55 (95\% $\mathrm{Cl}: 3.70-11.61)]$, and prior history of carbapenem use $[\mathrm{p}=0.003$, OR: 2.45 (95\% $\mathrm{Cl}: 1.36-4.41)$ were found to be the independent risk factors for $\mathrm{CRAB}$ colonization. When multivariate analysis was performed for risk factors for $A$. baumannii infections, CRAB colonization [ $p=0.000,0 R$ : 8.25 (95\% $\mathrm{Cl}$ : 3.51-19.40), mechanical ventilator use $[\mathrm{p}=0.016$, OR: 3.38 (95\% Cl: 1.25-9.149)], staying $\geq 15$ days in ICU [p=0.000, 0R: 11.17 (95\% Cl: $3.59-34.71)]$, and prior history of carbapenem use [p=0.000, OR: 2.63 (95\% Cl: 1.19-5.86)] were detected as independent risk factors.

Conclusion: CRAB colonization leads to infection. Taking the necessary precautions in ICUs before colonization is important. Keywords: Epidemiology, surveillance culture, antibacterial drug resistance, intensive care units, multiplex polymerase chain reaction

Öz

Giriş: Karbapenem dirençli Acinetobacter baumannii (KDAB) izolatları yoğun bakım ünitelerinde (YBÜ) ciddi tehditlerdendir. Bu çalışmada yetişkin yoğun bakım hastalarında KDAB kolonizasyonu ve enfeksiyonu ile ilişkili risk faktörlerinin araştırılması amaçlanmıştır.

Gereç ve Yöntem: Cerrahi/medikal YBÜ'de 48 saatten fazla hastaneye yatırılan hastalar KDAB edinimi için tarandı. Çevre kültürleri alındı. Tanımlama ve antibiyotik duyarlılığı Vitek 2 (bioMérieux, Fransa) ile belirlendi. b/a ${ }_{O X A-23}, b / a_{O X A-40}, b / a_{O X A-51}$ ve bla ${ }_{O X A-58}$ genleri, bir multipleks polimeraz zincir reaksiyonu (Hyplex ${ }^{\circledR}$ Carb0xa ID, Almanya) ile araştırıldı. DiversiLab (bioMérieux, Fransa) klonal ilişki analizi için kullanıldı. Verilerin karşılaştırılması için ki-kare ve t-testi kullanıldı. Lojistik regresyon geriye LR modeli, YBÜ KDAB edinimi ile bağımsız olarak ilişkili faktörleri değerlendirmek için yapıldı.

Cite this article as: Aksu Koca N, Baran I, Yetkin MA, Kanyılmaz D, Mumcuoğlu İ, Yağmurdur H, Baştuğ A, Alaçam S, Mutlu NM, Bodur H. Carbapenem-resistant Acinetobacter baumannii in Adult Intensive Care Units: Risk Factors for Colonization and Infection. Mediterr J Infect Microb Antimicrob. $2018 ; 7: 25$.

Presented in: Part of this study was presented as a poster presentation in $24^{\text {th }}$ ECCMID in May 2014.

Published: 28 August 2018 
Bulgular: Taranan 310 hastanın103'ü $(\% 33,2)$ KDAB ile kolonize idi. Hepsinde bla $a_{O A-23}$ ve bla ${ }_{O X A-51}$ genleri olumlu bulundu. DiversiLab izolatların çoğunun tek bir klondan geldiğini gösterdi. Klinik enfeksiyona karşı asemptomatik taşıyıcılık oranı yaklaşık 1:2 idi. KDAB kolonizasyonu için bağımsız risk faktörleri, bilinçsizlik durumu [p=0,049, OR: 2,37 (\%95 Cl: 1,35-4,14), YBÜ'de $\geq 15$ gün kalma [p=0,000, 0R: 6,55 (\%95 Cl: 3,70-11,61)] ve karbapenem kullanım öyküsü [ $p=0,003,0 R: 2,45(\% 95 \mathrm{Cl}: 1,36-4,41)$ olarak bulunmuştur. $A$. baumannii enfeksiyonları için risk faktörleri açısından çok değişkenli analiz yapıldığında, KDAB kolonizasyonu [p=0,000, OR: 8,25 (\%95 Cl: 3,51-19,40), karbapenem kullanım öyküsü [p=0,000, OR: 2,63 (\%95 Cl: 1,19-5,86)], mekanik ventilatör kullanımı [ $p=0,016,0 R: 3,38$ (\%95 Cl: 1,25-9,149) ve YBÜ'de $\geq 15$ gün kalma [p=0,000, OR: 11,17 (\%95 Cl: 3,59-34,71)] bağımsız risk faktörleri olarak tespit edilmiştir.

Sonuç: KDAB kolonizasyonu enfeksiyona neden olmaktadır. Kolonizasyon öncesi YBÜ'lerde gerekli önlemlerin alınması önemlidir.

Anahtar Kelimeler: Epidemiyoloji, sürveyans kültürü, antibakteriyal ilaç direnci, yoğun bakım ünitesi, multipleks polimeraz zincir reaksiyonu

\section{Introduction}

Healthcare-associated infections caused by carbapenemresistant Acinetobacter baumannii (CRAB) have been reported worldwide $\mathrm{e}^{[1-3]}$. These microorganisms may cause severe infections and even outbreaks in high-risk units of hospitals, such as intensive care units (ICUs) due to their abilities to survive on inanimate hospital surfaces and to gain antimicrobial resistance. As a result of these invasive infections, increased morbidity and mortality have been reported in predisposed patients ${ }^{[4,5]}$. Moreover, since $A$. baumannii can easily disseminate from patients to the hospital environment, the control of this microorganism within the ICU can be problematic ${ }^{[6]}$.

Ambler class D oxacillinases (OXA enzymes) with carbapenemhydrolyzing activity, have become one of the main sources of resistance in $A$. baumannii during the recent years ${ }^{[7]}$. Among the genes encoding OXA-type carbapenemases, there are four main subgroups associated with $A$. baumannii: the chromosomally located intrinsic b/a $a_{O X A-51-l i k e}$ and the acquired bla $a_{O X A-23-l i k e,} b / a_{O X A-}$ 40-like' $b_{\text {OXA-58-like }}^{[8,9] \text {. }}$

In previous studies, the risk factors for colonization and infection by CRAB have been outlined ${ }^{[2-5,10]}$. However, more data regarding monoclonal spread, either by colonization/infections or environmental contamination caused by $C R A B$, are needed to develop the best methods for managing this microorganism. Rapid investigation of the clonal relationships between strains could help prevent outbreaks by undertaking necessary infection control precautions in hospitals.

The aims of the present study were as follows: (1) to determine the risk factors for colonization and/or infection caused by CRAB; (2) to determine the oxacillinase genes responsible for carbapenem resistance and evaluate antimicrobial resistance patterns; and (3) to analyze the genetic similarities of the isolates.

\section{Materials and Methods}

\section{Settings}

This prospective observational study was performed in a Turkish State Research and Training Hospital from May 2012 to April
2013. This is a 1200-bed tertiary refererral hospital, serving not only a population of 5.445 .000 inhabitants but also those from the surrounding cities. There are 6 major ICUs (3 medical/ surgical, cardiac, neurosurgery, cardiovascular and thoracic) in the hospital, and this study was performed in two of them, which were medical/surgical ICUs (M/S ICU-1, M/S ICU-2). Either medical or surgical patients were admitted to these ICUs. These were open ICUs and there were 12 and 6 beds at M/S ICU-1 and M/S ICU-2, respectively, and in M/S ICU-1, two isolation beds were available. The patient-to-nurse ratio was 2:1 for the daytime shifts and 3:1 for the night shifts. Due to the lack of staff in these ICUs, there were not enough personnel in night shifts. On the other hand, these ICUs met the level 3 ICU criteria. An infection control program that included review and implementation of infection control protocols, use of educational sessions, and regular reporting of surveillance results was implemented. An antibiotic restriction policy has been applied in the hospital, and according to this restriction, a prior consultation with an infectious diseases specialist was required for carbapenems, piperacillin (PIP)/tazobactam (TZP), intravenous quinolones, glycopeptides and colistin.

\section{Study Design, Variables and Definitions}

All adult patients $\geq 18$ years old, who were hospitalized in the $\mathrm{M} / \mathrm{S}$ ICU for more than 48 hours, were included in the study and screened for CRAB acquisition. At admission to the ICUs, active surveillance cultures (urine, blood, nasal, rectal swabs and/or sputum) were obtained from all patients. Rectal swab cultures were obtained weekly until discharge. When CRAB strains were isolated only from rectal swab cultures, without any sign of infection, the patients were considered to be colonized. Colonized patients, could not be isolated from other patients due to lack of enough physical space in the ICUs. Clinical samples were obtained from bronchoaspirate, urine, bronchoalveolar lavage, blood and other biological fluids. Only the initial strain isolated from each patient was included in the study. The patient was considered to be infected by A. baumannii (isolated from a clinical specimen) when clinical signs were present and all other sources of infection were excluded. When it was not possible to identify whether the status of the patient was infected or colonized, the patient was considered colonized only. 
Healthcare-associated infections, such as ventilator-associated pneumonia, urinary tract infection or blood stream infections, were classified by using the Center for Disease Control and Prevention (CDC) criteria ${ }^{[11]}$.

Weekly environmental cultures from bed heads, infusion pumps, trolleys, manometers, door handles, soap dispensers, taps, shelves, and sink tops and hand cultures from healthcare personnel were also performed. Swabs moistened with brain-heart infusion broth (BHI) supplemented with $0.5 \%$ beef extract were used in environmental sampling. Then, swabs were dipped back into BHI. A $100 \mu \mathrm{L}$ sample of the BHI was inoculated onto $5 \%$ sheep blood agar and incubated at $37^{\circ} \mathrm{C}$ over nightly. Patients hospitalized for less than 48 hours in the ICU or who had an infection due to A. baumannii at admission were excluded from the study.

The following data were collected: age, sex, chronic underlying conditions (diabetes, chronic pulmonary diseases, cardiopulmonary diseases, solid tumors, hematological diseases, immunologic status), reason for ICU admission, presence of community-acquired infection, previous antibiotic usage, ICU length of stay before the isolation of $A$. baumannii, therapy, recent surgery, presence of invasive procedures (parenteral nutrition, intubation or tracheotomy, and central venous catheter), and presence of nosocomial infection according to the $C D C$ criteria.

For this study, a file was prepared for the Scientific Research Examination and Support Board of our hospital (before 2015 there was no ethical committee established in our hospital. Scientific Research Examination and Support Board worked as an instutional review board and granted necessary permits for scientific studies held in our hospital). In this file, conformity with the principles of the Declaration of Helsinki was assured by all researchers who participated in the study. Since it was an observational prospective study not constituting an extra risk for the patient, additional ethics committee approval was waived.

For the detection of CRAB in rectal swabs, a modification of the CDC protocol was used. Rectal swabs were incubated overnight in $5 \mathrm{~mL}$ of trypticase soy broth with a $10 \mathrm{mg}$ ertapenem disc. Then, $100 \mu \mathrm{L}$ of the incubated broth was subcultured on an eosin methylene blue (EMB) agar plate. After that, EMB agar was examined for lactose-nonfermenting bacteria. Identification of the isolates was done with a Vitek 2 (bioMerieux, France) system. A Maldi Biotyper (Bruker Daltonics, Germany) was used to confirm isolates as A. baumannii. Vitek GN AST cards were used to determine susceptibility to ampicillin-sulbactam (SAM), PIP/TZP, ceftazidime (CAZ), cefoperazone-sulbactam, cefepime (FEP), imipenem (IPM), meropenem (MEM), amikacin (AMK), gentamicin (GEN), netilmicin (NET), ciprofloxacin (CIP), levofloxacin, tetracycline (TET), tigecycline (TGC), CST, and trimethoprim-sulfamethoxazole (SXT). The MICs of IPM, MEM, TGC and CST were additionally determined by E-test strips (bioMérieux, France). They were interpreted according to the Clinical and Laboratory Standards Institute breakpoints, except for TGC, for which the European Committee on Antimicrobial Susceptibility Testing MIC breakpoints for Enterobacteriaceae were used $^{[12,13]}$. Escherichia coli ATCC 25922 and Pseudomonas aeruginosa ATCC 27853 were used as reference strains. To investigate the most common carbapenemase genes, a multiplex polymerase chain reaction (PCR) was performed for $b / a_{\text {OXA-23-like' }} b / a_{\text {OXA-40-like' }} b / a_{O X A-51-l i k e^{\prime}}$ and bla $a_{\text {OXA-58-like }}$ genes with the Hyplex Carb0xa ID test system (Amplex Diagnostics GmbH, Gars-Bahnhof, Germany), according to the manufacturer's instructions. Typing of the isolates was performed using a semiautomated rep-PCR DiversiLab System (bioMérieux, France), following the manufacturer's instructions. The results were analyzed with DiversiLab software, using the modified KullbackLeibler statistical method to determine distance matrices and the unweighted pair group method with arithmetic averages to create a dendrogram. Isolates that clustered at $>95 \%$ were considered related.

\section{Statistical Analysis}

A univariate analysis was performed to determine the variables associated with colonization and infection with CRAB. Contingency tables were analyzed by the two-tailed $\chi^{2}$ test or Fisher's exact test. Differences were considered significant at a $p$ value of $\leq 0.05$. Quantitative variable differences between case and control patients were compared by the Student's t-test. A multiple-regression logistic model was performed to identify the potential independent risk factors for colonization/ infection. Exposure variables with a $p$ value of $\leq 0.1$ in the univariate analysis were included and selected using a stepwise backward process.

\section{Results}

A total of 310 patients were screened during the study period. One hundred fifty-one (48.7\%) of them were male, the mean age was $66.9 \pm 17.8$ years. The mean length of the hospital stay was $17.5 \pm 21.7$ days (2-150 days). Demographic variables, comorbid conditions, invasive procedures, and the use of antimicrobials and other drugs are presented in detail in Table 1. One hundred three (33.2\%) patients were colonized with CRAB. Infection occurred in $48(43.7 \%)$ of the colonized patients, and the clinical infection versus asymptomatic carriage ratio was approximately 1:2.

CRAB colonization was detected in 103 patients, and the mean duration of time for colonization was $14.2 \pm 10.3$ days (3-55 days). The frequencies of predisposing factors were compared to investigate potential risk factors for CRAB colonization, and the results are shown in Table 2. The significant quantitative 
variables were found to be the mean length of ICU stay and APACHE II score at admission (Table 2). Other qualitative variables that showed statistical significance were presence of a central venous catheter or percutaneous endoscopic gastrostomy, intubation, previous history of ICU admission and administration of carbapenems $(p<0.05)$. Status of unconsciousness $[p=0.049$, OR: 2.37 (95\% Cl: 1.35-4.14)], staying $\geq 15$ days in ICU [ $p=0.000$, OR: 6.55 (95\% Cl: 3.70-11.61)] and prior history of carbapenem use ( $p=0.003,0 R: 2.45$ [95\% Cl: $1.36-4.41)$ were found as the independent risk factors for CRAB colonization in multipleregression logistic model.

A total of 48 patients had infections caused by CRAB. CRAB was isolated in rectal samples of all the infected patients. The ratio of CRAB colonization-to-infection was approximately as 2:1. Similar risk factors found significant for $C R A B$ colonization were also detected to be significant for CRAB infection (Table 3). Unlike CRAB-colonized patients, CRAB infection were more frequently detected in patients who were mechanically ventilated and those receiving enteral nutrition $(p<0.05)$. When the multivariate analysis was performed for risk factors for CRAB infection, CRAB colonization [ $\mathrm{p}=0.000$, OR: 8.25 (95\% Cl: 3.51-19.40)], mechanical ventilator use $[p=0.016$, OR: 3.38
(95\% Cl: $1.25-9.149)]$, staying $\geq 15$ days in ICU [p=0.000, OR: 11.17 (95\% Cl: 3.59-34.71)], and prior history of carbapenem use [p=0.000, OR: 2.63 (95\% Cl: 1.19-5.86)] were detected to be independent risk factors. The mortality rates in infected patients at 14 days and 30 days were detected to be higher than in controls $(p<0.05)$.

CRAB infection was detected approximately $19.2 \pm 14.6$ days after admission. The most frequent site of infection detected in these ICU patients were ventilator-associated pneumonia (74.5\%), surgical site infections (14.6\%) and blood stream infections (10.6\%).

During the study period, 103 CRAB strains were isolated from rectal swab samples and 48 from clinical samples. CRAB isolates were most frequently isolated from tracheal aspirate/sputum samples (36 of the cases), followed by surgical wounds (7 of the cases) and blood (5 of the cases).

A. baumannii was isolated $19(25 \%)$ times from the 76 different environmental samples collected during the study period. These A. baumannii isolates were also included in our study. There were no $A$. baumannii strains isolated from hand cultures of the staff.

Table 1. Epidemiologic and predisposing features of patients colonized or infected with $A$. baumannii

\begin{tabular}{|c|c|c|c|}
\hline Variable & $\begin{array}{l}\text { Whole study patients } \\
\qquad \mathrm{N}=310(\%)\end{array}$ & $\begin{array}{c}\text { Colonized with CRAB } \\
\qquad \mathrm{N}=103(\%)\end{array}$ & $\begin{array}{c}\text { Infected with CRAB } \\
\qquad \mathrm{N}=48(\%)\end{array}$ \\
\hline Male sex & $151(48.7)$ & $54(52.4)$ & $25(52.1)$ \\
\hline Median age, years & $66.9 \pm 17.8$ & $69.1 \pm 16.4$ & $71.6 \pm 14.9$ \\
\hline APACHE II at admission & $17.47 \pm 7.24$ & $19.52 \pm 6.66$ & $20.26 \pm 4.91$ \\
\hline $\begin{array}{l}\text { Concomitant diseases } \\
\text { Chronic non-fatal CVD } \\
\text { Diabetes mellitus } \\
\text { Chronic pulmonary disease } \\
\text { Cancer } \\
\text { Neurologic disability }\end{array}$ & $\begin{array}{l}110(35.5) \\
72(23.2) \\
51(16.5) \\
57(18.4) \\
76(24.5)\end{array}$ & $\begin{aligned} 41 & (39.8) \\
31 & (30.1) \\
7 & (6.8) \\
16 & (15.5) \\
32 & (31.1)\end{aligned}$ & $\begin{array}{l}21(43.8) \\
15(31.3) \\
3(6.3) \\
6(12.5) \\
18(37.5)\end{array}$ \\
\hline Central venous catheter & $213(68.7)$ & $90(87.4)$ & 44 (91.7) \\
\hline Mechanical ventilation & $169(54.5)$ & $74(71.8)$ & $42(87.5)$ \\
\hline PEG & $22(7.1)$ & $15(14.6)$ & $7(14.6)$ \\
\hline Enteral feeding & $193(62.3)$ & $82(79.6)$ & 44 (91.7) \\
\hline Parenteral nutrition & $139(44.8)$ & $51(49.5)$ & $28(58.3)$ \\
\hline Trauma & $61(19.7)$ & $24(23.3)$ & $15(31.3)$ \\
\hline Surgery & 95 (30.6) & $36(35.0)$ & $16(33.3)$ \\
\hline Steroid usage & $81(26.1)$ & $17(16.5)$ & $9(18.8)$ \\
\hline Disturbances in the consciousness on physical examination & $169(54.5)$ & $36(65.0)$ & $30(62.5)$ \\
\hline Prior history of ICU admission & $61(19.7)$ & $32(31.1)$ & $14(29.2)$ \\
\hline Mean duration of length of stay & $17.54 \pm 21.69$ & $30.43 \pm 28.29$ & $41.00 \pm 27.22$ \\
\hline $\begin{array}{l}\text { Prior antibiotic usage } \\
\text { Piperacillin/tazobactam } \\
\text { Cephalosporin } \\
\text { Carbapenem } \\
\text { Fluoroquinolones } \\
\end{array}$ & $\begin{array}{l}76(24.5) \\
76(24.5) \\
87(28.1) \\
46(14.8) \\
\end{array}$ & $\begin{array}{l}28(27.2) \\
18(17.5) \\
46(44.7) \\
12(11.7) \\
\end{array}$ & $\begin{aligned} & 13(27.1) \\
& 4(8.3) \\
& 27(56.3) \\
& 2(4.2) \\
&\end{aligned}$ \\
\hline Mortality in 30 days & $102(32.9)$ & $46(44.7)$ & $32(66.7)$ \\
\hline
\end{tabular}

CRAB: Carbapenem-resistant A. baumannii, CVD: Cardiovascular disease, PEG: Percutaneous endoscopic gastrostomy, ICU: Intensive care units 
Table 2. Matched univariate and multivariate analyses of risk factors for carbapenem-resistant A. baumannii colonization $^{\dagger}$

\begin{tabular}{|c|c|c|c|c|c|}
\hline & \multirow[t]{2}{*}{$\begin{array}{l}\text { CRAB colonized } \\
\mathrm{N}=103\end{array}$} & \multirow[t]{2}{*}{$\begin{array}{c}\text { Not CRAB colonized } \\
\mathrm{N}=\mathbf{2 0 7}\end{array}$} & \multirow{2}{*}{$\begin{array}{c}\begin{array}{c}\text { Univariate } \\
\text { analysis }\end{array} \\
p\end{array}$} & \multicolumn{2}{|c|}{ Multivariate analysis } \\
\hline & & & & $\mathbf{p}$ & OR (95\% Cl) \\
\hline Age (years) & $69.08 \pm 16.4$ & $65.9 \pm 18.4$ & 0.139 & & \\
\hline Male sex & 54 & 97 & 0.399 & & \\
\hline APACHE II score & $19.5 \pm 6.8$ & $16.4 \pm 7.3$ & 0.000 & & \\
\hline \multicolumn{6}{|l|}{ Comorbid conditions } \\
\hline Chronic pulmonary disease & 7 & 15 & 1.00 & & \\
\hline Chronic cardiovascular disease & 41 & 66 & 0.205 & & \\
\hline Diabetes mellitus & 31 & 41 & 0.047 & & \\
\hline Neurologic disability & 32 & 49 & 0.172 & & \\
\hline Renal failure & 2 & 10 & 0.349 & & \\
\hline Cancer & 16 & 41 & 0.437 & & \\
\hline \multicolumn{6}{|l|}{ Predisposing factors } \\
\hline Central venous catheter & $90(87.4)$ & $123(59.4)$ & 0.000 & 0.194 & $1.62(0.74-3.31)$ \\
\hline Mechanical ventilator & $74(71.8)$ & $95(45.9)$ & 0.000 & 0.913 & $1.04(0.53-2.02)$ \\
\hline Presence of PEG & $15(14.6)$ & $7(3.4)$ & 0.000 & 0.724 & $1.26(0.35-4.55)$ \\
\hline Parenteral nutrition & $51(49.5)$ & $88(42.5)$ & 0.276 & & \\
\hline Enteral feeding & $82(79.6)$ & $111(53.6)$ & 0.000 & 0.771 & $1.11(0.54-2.20)$ \\
\hline Immunosuppression & $8(7.8)$ & $15(7.2)$ & 0.823 & & \\
\hline Being on hemodialysis & $12(11.7)$ & $19(9.2)$ & 0.548 & & \\
\hline Surgery & $36(35.0)$ & $59(28.5)$ & 0.295 & & \\
\hline Previous history of ICU hospitalization & $32(31.1)$ & $29(14.0)$ & 0.01 & 0.521 & $1.27(0.64-2.54)$ \\
\hline Mean length of ICU stay (days) & $30.4 \pm 28.2$ & $11.2 \pm 13.6$ & 0.000 & 0.000 & $0.95(0.93-0.98)$ \\
\hline $\begin{array}{l}\text { Duration of ICU stay } \\
\quad \quad \quad \leq 14 \text { days } \\
\quad \leq 15 \text { days }\end{array}$ & $\begin{array}{l}26 \\
70\end{array}$ & $\begin{array}{c}158 \\
56\end{array}$ & 0.000 & 0.000 & $6.55(3.70-11.61)$ \\
\hline Disturbances in the consciousness on physical examination & $67(65.0)$ & $74(35.7)$ & 0.000 & 0.049 & $2.37(1.35-4.14)$ \\
\hline $\begin{array}{l}\text { Prior antibiotic usage } \\
\text { Piperacillin/tazobactam } \\
\text { Cephalosporin } \\
\text { Carbapenem } \\
\text { Fluoroquinolones }\end{array}$ & $\begin{array}{l}28(27.2) \\
18(17.5) \\
46(44.7) \\
12(11.7)\end{array}$ & $\begin{array}{l}48(23.2) \\
58(28.0) \\
41(19.8) \\
34(16.4)\end{array}$ & $\begin{array}{l}0.484 \\
0.050 \\
0.000 \\
0.311 \\
\end{array}$ & 0.003 & $2.45(1.36-4.41)$ \\
\hline Mortality in 30 days & $46(44.7)$ & $56(27.1)$ & 0.005 & & \\
\hline
\end{tabular}

CRAB: Carbapenem-resistant $A$. baumannii, ${ }^{+}$: Data are expressed as numbers (\%) of patients except where stated, PEG: Percutaneous endoscopic gastrostomy, ICU: Intensive care units

All strains isolated from clinical samples and rectal swabs were found to be resistant to PIP, TZP, CAZ, FEP, IPM, MEM, CIP and LEV; $99.25 \%$ of isolates were resistant to SAM, $83.85 \%$ were resistant to CES, $68.31 \%$ were resistant to AMK, $61.27 \%$ were resistant to GEN, $25.78 \%$ were resistant to NET, $78.20 \%$ were resistant to TET, $20.30 \%$ were resistant to TGC, and $67.61 \%$ were resistant to SXT. The most active agent against all the isolates was colistin (99.3\% sensitive).

When analyzed by multiplex PCR, all the isolates, including the isolates from environmental samples, were found to have the $b / a_{O X A-23}$ and $b l a_{O X A-51}$ genes; in contrast, the $b / a_{O X A-40}$ and $b l a_{O X A-58}$ genes were not detected in any of them.

Molecular typing of 157 CRAB isolates (102 from rectal swabs, 36 from clinical samples, 19 from environmental samples) was performed using the DiversiLab system. We tried to study all the samples with DiversiLab system, but we got valid results from only 157 of the samples. Using a similarity index of $>95 \%$, $129(82.17 \%)$ isolates (86 from rectal samples, 25 from clinical samples and 18 from the environmental samples) were clustered into one large cluster (Figure 1). The majority of the CRAB isolates in the cluster (97.67\%) were multidrug resistant. 
Table 3. Matched univariate and multivariate analyses of risk factors for carbapenem-resistant A. baumannii infection $^{\dagger}$

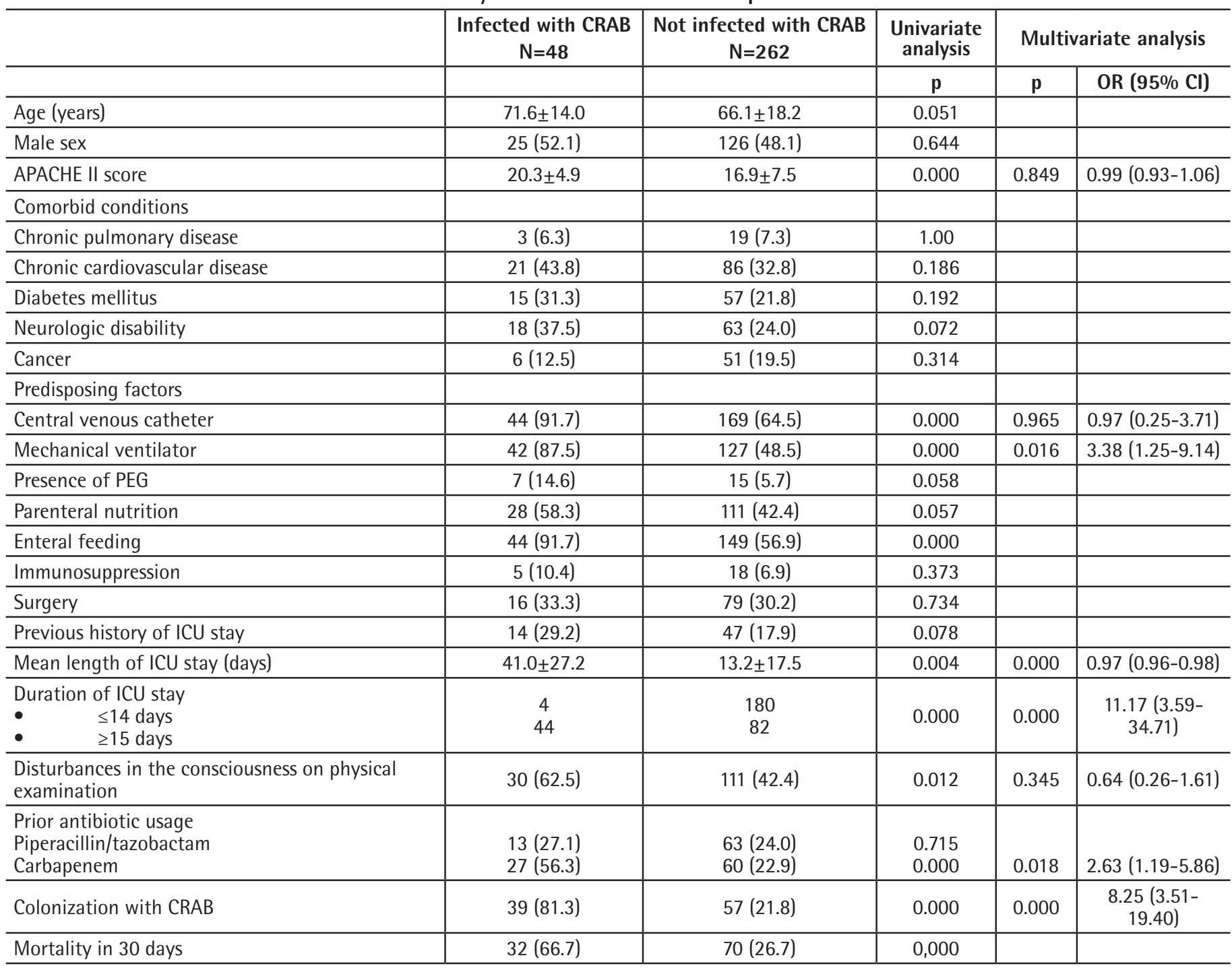

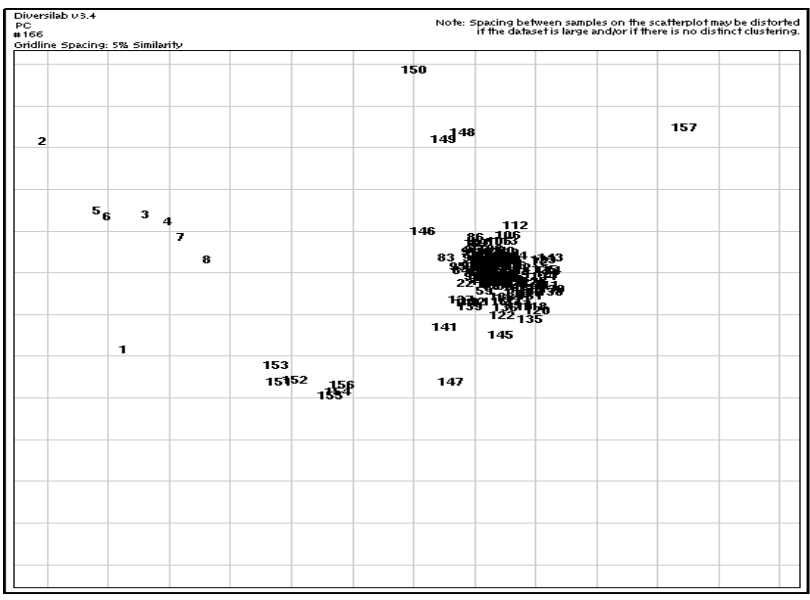

Figure 1. Scatter plot analysis graph of carbapenem-resistant Acinetobacter baumannii isolates analyzed by the DiversiLab (bioMérieux, France) system

\section{Discussion}

Hospital acquired infections due to CRAB cause serious problems in ICUs; moreover, they tend to spread to the other parts of hospitals ${ }^{[1-3]}$. In order to develop the best means of controlling this microorganism, more data regarding monoclonal spread, either colonization or infections, caused by CRAB are needed. Herein, we provide comprehensive information about the molecular and clinical epidemiology, antimicrobial susceptibility patterns and monoclonal spread of CRAB in a developing country setting.

In the pathogenesis of hospital-acquired infections, colonization is the first step most of the time. In our study, colonization appeared approximately in two weeks time. In previous studies the length of ICU stay was an important factor for CRAB colonization or infection, and the colonization ratio 
increased when the length of stay was prolonged ${ }^{[2,14]}$. At the end of our study, we detected that the mean ICU length of stay in colonized or infected patients was longer than non-infected or non-colonized patients. A high APACHE II score, a presence of invasive devices and a history of previous ICU hospitalization were all significant risk factors by the univariate analysis for both CRAB colonization and infection. Reduced consciousness on physical examination was a risk factor for both colonization and infection by CRAB. Since patients with disturbances in the consciousness may have impaired nasopharyngeal protective mechanisms, and they require intubation more than others, microorganisms are easily able first to colonize and then to infect the host. The current study showed that invasive procedures, such as intubation and colonization with CRAB, were independent risk factors, as seen by the multivariate analysis of CRAB infection. In most studies investigating the pathogenesis of ventilator-associated pneumonia, it has been shown that intubation tubes could be colonized easily by microorganisms, and after this step, infection could occur ${ }^{[15-18]}$. Our study results were consistent with these studies.

Previous studies have repeatedly shown that there was a correlation between antibiotic exposure and multidrug resistance emergence ${ }^{[2,19,20]}$. Antibiotics generate resistance, and they have a selective pressure effect on resistance genes. As a result of our study, only carbapenem use was found to be an independent risk factor for CRAB infections.

In some of the studies, an association between increased mortality and prolonged hospital and ICU stays due to CRAB was detected, but mortality rate was not found to be high when the severity of illness or underlying conditions were adjusted ${ }^{[10,20]}$. In our study, the mortality rate was higher in both CRAB-colonized and CRAB-infected patients. For the treatment of CRAB-infected patients, only CST could be used. During the study period, due to the reimbursement rules of Republic of Turkey Social Security Institution (SGK), CST was administered only when the infection was documented microbiologically. This situation caused a time gap for treatment between the beginning of infection and its microbiologic documentation. We believe that this late treatment start might have caused the high mortality rate.

In our study, CRAB was isolated from clinical samples, surveillance cultures and the environment. As a result of the analysis of these CRAB strains, all of them possessed the bla $a_{O X A-51}$ gene and bla ${ }_{O X A-23}$ gene, and none of them harboured the bla $a_{O X A-40}$ and $b / a_{O X A-58}$ genes, similar to previous studies from our region ${ }^{[21,22]}$. The $b l a_{O X A-51}$ gene is an intrinsic chromosomal gene naturally occurring in all $A$. baumannii strains ${ }^{[8,23]}$. Among various mechanisms of carbapenem resistance OXA enzymes have become one of the main sources of resistance in recent years ${ }^{[7]}$. OXA-23 enzymes spread to many worldwide locations including Europe (including Turkey), Asia, and South
America ${ }^{[22-27]}$. Between 1999 and 2009, CRAB isolates from several Mediterranean countries, including Greece, Turkey and Italy, predominantly carried the $b / a_{O X A-58}$ carbapenemase gene. Since 2009, OXA-58 has been increasingly replaced by OXA23 in these countries ${ }^{[28]}$. Perez et al. ${ }^{[25]}$ reported that global spread of CRAB was associated with a multidrug-resistant clone designated as European or International clone II, which harbours the bla $a_{O X A-23}$ gene. According to our results, although all the isolates harboured the $b / a_{O X A-51}$ gene, OXA-23 was the main oxacillinase enzyme for resistance to carbapenems in CRAB strains isolated from our hospital.

When analyzed by rep-PCR, the CRAB isolates formed one large cluster in our hospital. In previous studies, it was observed that A. baumannii outbreaks usually originated from a single clone or a single dominant clone ${ }^{[8,29,30]}$. CRAB isolates isolated from 18 of the 19 environmental samples (94.74\%) were in the large cluster. This finding suggested that the environment probably acted as a reservoir in the spread of CRAB in the hospital. Similar results have been previously reported ${ }^{[29]}$. Our data suggest that cross-contamination between patients and environmental surfaces cause the persistence of CRAB in our hospital.

In our study, CRAB isolates were found to be highly resistant to the majority of the tested antibiotics. CST was the most effective antibiotic. TGC and NET were found to be the next most effective antibiotics after CST. In several studies conducted worldwide, as well as in Turkey, CST and TGC were reported to be most effective antimicrobial agents against multidrug resistant A. baumannif ${ }^{[8,20,27,29,31]}$. In our study, all the isolates were resistant to IPM and MEM. Resistance to carbapenems is usually accompanied by resistance to other antibiotics, which limits the options for therapy ${ }^{[27,29]}$. In agreement with these data, we found that the CRAB isolates were also highly resistant to many antibiotics in general use. The majority of the isolates in the dominant clone were multidrug resistant.

As an additional note, CRAB rates in our patients were found to be higher in the 10\%, 25\%,50\% and 75\% percentiles than the UHESA (National Hospital Infections Surveying System) report percentiles and the same in the $90 \%$ percentile (100), as in the other education and research hospitals in 2012-2013 ${ }^{[32]}$.

There were several limitations of this study. First of all, due to economic inadequacy, the study was designed for a limited duration and only limited number of patients was included in the study. Similarly, active surveillance cultures could not be performed as frequently as desired, this was especially important to detect the specific day of CRAB colonization accurately. Also, hand hygiene rates have not been checked during our study. Besides these facts, although the patients were followed closely for their clinical status and microbiological results, it was sometimes very difficult to decide whether the patients 
were colonised or infected. CRAB screening was performed 48 hours after hospitalization. No screening was done at the first hospitalization. In addition, CRAB isolation rate in the previous year for the ICUs, for which we conducted our study, had not been recorded. Thus, we did not have the opportunity to compare our results with those of the previous year. The strengths of our study include that this was a prospective study and performed at two different ICUs, reference techniques were used for processes such as identifying $A$. baumannii, testing the antimicrobial susceptibility pattern and determining the molecular typing of the isolates.

\section{Conclusions}

In conclusion, by using rapid diagnostic methods, we detected that most of our patients were colonized and/or infected with only one clone of CRAB. In addition, strains belonging to this large clone were also isolated from environmental cultures. All these facts indicated that healthcare personnel compliance with infection control measures was relatively poor. Although CRAB was not isolated from healthcare workers' hands, we believe that, after the contamination of the environment with CRAB, healthcare personnel's hands were the responsible agent for the spread of the microorganism in the hospital.

\section{Ethics}

Ethics Committee Approval: For this study, a file has been prepared for the Scientific Research Examination and Support Board of our hospital. In this file, the Declaration of Helsinki was signed by all researchers who participated in the study. Since it was an observational, prospective study, in the form of routine examinations for the patient that does not constitute an extra risk, additional ethics committee approval was waived.

Informed Consent: Since it was an observational, prospective study, in the form of routine examinations for the patient that does not constitute an extra risk, the need for informed consent was waived.

Peer-review: Externally and internally peer-reviewed.

\section{Authorship Contributions}

Surgical and Medical Practices: H.Y., N.M.M., D.K., Concept: I.B., N.A.K., H.B., Design: I.B., M.A.Y., D.K., Data Collection or Processing: I.B., M.A.Y., D.K., I.M., Analysis or Interpretation: I.B., M.A.Y., D.K., A.B., Literature Search: I.B., M.A.Y., D.K., S.A., Writing: I.B., M.A.Y., H.B.

Conflict of Interest: No conflict of interest was declared by the authors.

Financial Disclosure: This study was funded by Scientific Research Support Board of Ankara Numune Training and Research Hospital. The funding source had no involvement in study design; in the collection, analysis and interpretation of data; in the writing of the report; and in the decision to submit the article for publication. The funding source only provided necessary budget to supply equipment for laboratory tests.

\section{References}

1. Lambert ML, Suetens C, Savey A, Palomar M, Hiesmayr M, Morales I, Agodi A, Frank U, Mertens K, Schumacher M, Wolkewitz M. Clinical outcomes of healthcare-associated infections and antimicrobial resistance in patients admitted to European intensive-care units: a cohort study. Lancet Infect Dis. 2011;11:30-8.

2. Ye JJ, Huang CT, Shie SS, Huang PY, Su LH, Chiu CH, Leu HS, Chiang PC. Multidrug resistant Acinetobacter baumannii: risk factors for appearance of imipenem resistant strains on patients formerly with susceptible strains. PLoS One. 2010;5:e9947.

3. Villar M, Cano ME, Gato E, Garnacho-Montero J, Miguel Cisneros J, Ruíz de Alegría $C$, Fernández-Cuenca $F$, Martínez-Martínez L, Vila J, Pascual $A$, Tomás M, Bou G, Rodríguez-Baño J; GEIH/GEMARA/REIPI-Ab20101 Group. Epidemiologic and clinical impact of Acinetobacter baumannii colonization and infection: a reappraisal. Medicine (Baltimore). 2014;93:202-10.

4. Del Mar Tomas M, Cartelle M, Pertega S, Beceiro A, Llinares $P$, Canle D, Molina F, Villanueva R, Cisneros JM, Bou G. Hospital outbreak caused by a carbapenem-resistant strain of Acinetobacter baumannii: patient prognosis and risk-factors for colonisation and infection. Clin Microbiol Infect. 2005;11:540-6.

5. Cristina ML, Spagnolo AM, Cenderello N, Fabbri P, Sartini M, Ottria G, Orlando P. Multidrug-resistant Acinetobacter baumannii outbreak: an investigation of the possible routes of transmission. Public Health. 2013;127:386-91.

6. Bergogne-Bérézin E, Towner KJ. Acinetobacter spp. as nosocomial pathogens: microbiological, clinical, and epidemiological features. Clin Microbiol Rev. 1996;9:148-65.

7. Park S, Kim HS, Lee KM, Yoo JS, Yoo Jl, Lee YS, Chung GT. Molecular and epidemiological characterization of carbapenem-resistant Acinetobacter baumannii in non-tertiary Korean hospitals. Yonsei Med J. 2013;54:177-82.

8. Higgins PG, Dammhayn C, Hackel M, Seifert H. Global spread of carbapenem-resistant Acinetobacter baumannii. J Antimicrob Chemother. 2010;65:233-8.

9. Walther-Rasmussen J, Høiby N. OXA-type carbapenemases. J Antimicrob Chemother. 2006;57:373-83.

10. Sunenshine $R H$, Wright $M O$, Maragakis $L L$, Harris $A D$, Song $X$, Hebden J, Cosgrove SE, Anderson A, Carnell J, Jernigan DB, Kleinbaum DG, Perl TM, Standiford HC, Srinivasan A. Multidrug-resistant Acinetobacter infection mortality rate and length of hospitalization. Emerg Infect Dis. 2007;13:97103.

11. Horan TC, Andrus M, Dudeck MA. CDC/NHSN surveillance definition of health care-associated infection and criteria for specific types of infections in the acute care setting. Am J Infect Control. 2008;36:309-32.

12. CLSI. Performance Standards for Antimicrobial Susceptibility Testing; Twenty-Fourth Informational Supplement. CLSI document M100-S24. Wayne, PA: Clinical and Laboratory Standards Institute; 2014.

13. The European Committee on Antimicrobial Susceptibility Testing. Breakpoint tables for interpretation of MICs and zone diameters. Version 4.0, 2014. Last accessed date: 25.05.2018. Available from: http://www.eucast.org.

14. Harris AD, Karchmer TB, Carmeli Y, Samore MH. Methodological principles of case-control studies that analyzed risk factors for antibiotic resistance: a systematic review. Clin Infect Dis. 2001;32:1055-61.

15. Filius PM, Gyssens IC, Kershof IM, Roovers PJ, Ott A, Vulto AG, Verbrugh HA Endtz HP. Colonization and resistance dynamics of gram-negative bacteria in patients during and after hospitalization. Antimicrob Agents Chemother 2005:49:2879-86. 
16. Bonten MJ, Weinstein RA. The role of colonization in the pathogenesis of nosocomial infections. Infect Control Hosp Epidemiol. 1996;17:193-200.

17. de Latorre FJ, Pont T, Ferrer A, Rosselló J, Palomar M, Planas M. Pattern of tracheal colonization during mechanical ventilation. Am J Respir Crit Care Med 1995;152:1028-33.

18. Bonten MJ, Bergmans DC, Ambergen AW, de Leeuw PW, van der Geest $\mathrm{S}$, Stobberingh EE, Gaillard CA. Risk factors for pneumonia, and colonization of respiratory tract and stomach in mechanically ventilated ICU patients. Am J RespirCrit Care Med. 1996;154:1339-46.

19. Ho PL, Ho AY, Chow KH, Lai EL, Ching P, Seto WH. Epidemiology and clonality of multidrug-resistant Acinetobacter baumannii from a healthcare region in Hong Kong. J Hosp Infect 2010;74:358-64.

20. Playford EG, Craig JC, Iredell JR. Carbapenem-resistant Acinetobacter baumannii in intensive care unit patients: risk factors for acquisition, infection and their consequences. J Hosp Infect. 2007;65:204-11.

21. Mansour W, Poirel L, Bettaieb D, Bouallegue O, Boujaafar N, Nordmann P. Dissemination of OXA-23-producing and carbapenem-resistant Acinetobacter baumannii in a University Hospital in Tunisia. Microb Drug Resist 2008;14:289-92.

22. Sarı B, Baran I, Alaçam S, Mumcuoğlu I, Kurşun Ş, Aksu N. Investigation of oxacillinase genes in nosocomial multidrug-resistant Acinetobacter baumannii isolates by multiplex PCR and evaluation of their clonal relationship with Rep-PCR. Mikrobiyol Bul. 2015;49:249-58.

23. Jiang W, Liu H, Zhong M, Yang YC, Xiao DW, Huang WF. Study on the resistant genes to carbapenems and epidemiological characterization of multidrug-resistant Acinetobacter baumannii isolates. Microb Drug Resist. 2013;19:117-23.

24. Nowak $\mathrm{P}$, Paluchowska $\mathrm{P}$, Budak A. Distribution of $b / a_{0 \times \mathrm{A}}$ genes among carbapenem-resistant Acinetobacter baumannii nosocomial strains in Poland. New Microbiol. 2012;35:317-25.
25. Perez F, Hujer AM, Hujer KM, Decker BK, Rather PN, Bonomo RA. Global challenge of multidrug-resistant Acinetobacter baumannii. Antimicrob Agents Chemother. 2007;51:3471-84.

26. Andriamanantena $T S$, Ratsima $E$, Rakotonirina $H C$, Randrianirina $F$, Ramparany L, Carod JF, Richard V, Talarmin A. Dissemination of multidrug resistant Acinetobacter baumannii in various hospitals of Antananarivo Madagascar. Ann Clin Microbiol Antimicrob. 2010;9:17.

27. Corrêa LL, Botelho LA, Barbosa LC, Mattos CS, Carballido JM, de Castro CL, Mondino PJ, de Paula GR, de Mondino SS, de Mendonça-Souza CR. Detection of bla $a_{0 \times-23}$ in Acinetobacter spp. isolated from patients of a university hospital. Braz J Infect Dis. 2012;16:521-6.

28. Liakopoulos A, Miriagou V, Katsifas EA, Karagouni AD, Daikos GL, Tzouvelekis LS, Petinaki E. Identification of OXA-23-producing Acinetobacter baumannii in Greece, 2010 to 2011. Euro Surveill. 2012:17.

29. Phumisantiphong $U$, Diraphat $P_{1}$ Utrarachkij $F_{1}$ Uaratanawong $S$, Siripanichgon K. Clonal spread of carbapenem resistant Acinetobacter baumannii in the patients and their environment at BMA Medical College and Vajira Hospital. J Med Assoc Thai. 2009;92 (Suppl 7):173-80.

30. Karagöz A, Baran I, Aksu N, Acar S, Durmaz R. Characterization and determination of antibiotic resistance profiles of a single clone Acinetobacter baumannii strains isolated from blood cultures. Mikrobiyol Bul. 2014;48:566-76.

31. Perez F, Endimiani A, Ray AJ, Decker BK, Wallace CJ, Hujer KM, Ecker DJ, Adams MD, Toltzis P, Dul MJ, Windau A, Bajaksouzian S, Jacobs MR, Salata RA, Bonomo RA. Carbapenem-resistant Acinetobacter baumannii and Klebsiella pneumoniae across a hospital system: impact of post-acute care facilities on dissemination. J Antimicrob Chemother. 2010;65:1807-18.

32. Ulusal Hastane Enfeksiyonları Sürveyans Ağı (UHESA). Son erişim tarihi: 28.01.2019. Erişim adresi: uhes.saglik.gov.tr/ 